\title{
New World Materia Medica in Spanish Renaissance Medicine: From Scholarly Reception to Practical Impact
}

\author{
TERESA HUGUET-TERMES*
}

\section{Introduction}

The objective of Christopher Columbus's voyage in 1492 was to find a new route to the legendary spice islands of the East. Europe wanted cheaper spices and a larger share of this lucrative market. So the colonization and exploitation of the vast American territories was in part driven by a search for plants that would be useful for either culinary or medicinal purposes. Columbus's letter to Luis de Santángel of $1493^{1}$ and the reports of Pedro Mártir de Anglería in $1511^{2}$ provide evidence of the potential economic importance of the exotic drugs found in the New World. ${ }^{3}$

But the assimilation and practical distribution of new therapeutic tools, especially simple drugs, and their incorporation into a well-structured Galenic medical system

* Teresa Huguet Termes, PhD, Departamento de Salud Pública e Historia de la Ciencia, Universidad Complutense, Madrid.

A first version of this paper was given at the symposium 'Medicine in the Renaissance Cities' held at the Wellcome Institute for the History of Medicine and at the Warburg Institute on March 1999 in London. Where no previous English translations of the primary sources used in this paper existed, quotations have been translated for the paper specifically.

This study was written as part of a larger ongoing research project on pharmacological therapy in late medieval and renaissance medical practice, funded by the Dirección General de Investigación Científica (Ministerio de Educación y Cultura, Spain) and carried out at the Wellcome Institute for the History of Medicine in London from 1998 to 2000 . I am particularly indebted to Vivian Nutton and José Pardo Tomás for their valuable suggestions and criticisms at many stages of this paper and for their revision of an earlier draft. I also wish to thank Jon Arrizabalaga, Janet Browne and Andrew Wear for their useful comments after reading earlier drafts. Also my gratitude goes to François Ledermann, Carlos Viesca Treviño and Ramón Jordi for providing me with materials to write this paper, and to Caroline Tonson-Rye for helping me to translate quotations in old Spanish as well as for correcting my English. However, any mistakes and misinterpretations are, of course, my own.

\footnotetext{
${ }^{1}$ Cristóbal Colón, Textos y documentos completos. Relaciones de viajes, cartas y
} memoriales, ed. Consuelo Varela, Madrid, Alianza Editorial, 1984, p. 146. For a survey of Latin editions as well as Italian and German translations, see José María López Piñero et al., Los impresos cientificos españoles de los siglos $X V$ y XVI. Inventario, 4 vols, Valencia, Cátedra de Historia de la Medicina, 1981-1986.

${ }^{2}$ Pedro Mártir de Anglería, Occeani decadis liber primus ... , Seville, Juan Cromberger, 1511. For a Spanish translation with an useful introduction, see R Alba, 'Introducción. Pedro Mártir de Anglería: su vida y su obra', in Pedro Mártir de Anglería, Décadas del Nuevo Mundo, Madrid, Polifemo, 1989, pp. V-XLIII.

${ }^{3}$ Francisco Guerra, 'Drugs from the Indies and the political economy of the sixteenth century', in M Florkin (ed.), Materia medica in the XVIth century: proceedings of a symposium of the International Academy of the History of Medicine held at University of Basel, 7th September 1964, Oxford and New York, Symposium Publications Division, Pergamon Press, 1966, pp. 29-54. 
had to overcome many obstacles in European as well as in Spanish medicine in the sixteenth century. ${ }^{4}$

As Guenter Risse ${ }^{5}$ has commented, at a time when the Spanish crown dominated a large part of Europe and was building up a world empire, most of the inhabitants of sixteenth-century Spain lived in rural areas. Diseases such as plague, leprosy, typhus and the great pox extended with demographic and economic consequences even through the upper and middle classes of society. Certain specific points are worth noting. There was a shortage of university-trained physicians and Latinate surgeons (those with academic training), who practised in cities and at the royal court and who were employed by municipalities and hospitals. These élite physicians treated members of the aristocracy and prominent clergymen. Other kinds of practitioners included non-Latinate surgeons often employed in the armies and navies, empirics who treated specific problems requiring practical skills, and also practitioners belonging to the Jewish and Morisco minorities marginalized into an illegal status by the Catholic majority. ${ }^{6}$ The Spanish crown created in 1477 the "Protomedicato": a body charged with the responsibility of regulating medical practitioners. ${ }^{7}$ Different trends within Galenic theory constituted the prevailing medical system of thought. ${ }^{8}$ There were as well a wide variety of European and Eastern drugs in circulation in huge quantities. All of this may have militated against the introduction of new medical theories and a new armamentarium.

The idea that only a few American drugs were used in Europe and therefore had little impact has been perpetuated without much questioning or investigation. Joseph Ewan stated that the bearing which Columbian discoveries had on the development of botanical concepts in sixteenth-century Europe was slight, and that our understanding of plants, their forms and functions was the result first of stumbling confusion, then of slow awakening during the centuries. ${ }^{9}$ There has, until recently,

\footnotetext{
${ }^{4}$ For useful surveys of the situation of Spanish medicine in the sixteenth century, see José María López Piñero, Ciencia y técnica en la sociedad española de los siglos XVI y XVII, Barcelona, Labor Universitaria, 1979, and Luis Sánchez Granjel, La medicina española renacentista, Universidad de Salamanca, 1980. For an interesting resumé in English, see José María López Piñero, 'The medical profession in 16th century Spain', in A W Russell (ed.), The town and the state physician in Europe from the Middle Ages to the Enlightenment, Wolfenbüttel, Herzog August Bibliothek, 1981, pp. 85-98.

${ }^{5}$ Guenter Risse, 'Medicine in New Spain', in R L Numbers (ed.), Medicine in the New World: New Spain, New France and New England, Knoxville, University of Tennessee Press, 1987, pp.12-24.

${ }^{6}$ Regarding Morisco practitioners especially, see Luis García Ballester, 'Academicism versus empiricism in practical medicine in sixteenthcentury Spain with regard to Morisco practitioners', in A Wear, R K French and I M Lonie (eds), The medical renaissance of the
}

sixteenth century, Cambridge University Press, 1985, pp. 246-342, and Luis García Ballester, Los moriscos y la medicina. Un capítulo de la medicina y la ciencia marginadas en la España del siglo XVI, Barcelona, Labor Universitaria, 1989.

${ }^{7}$ See J T Lanning, The Royal Protomedicato, the regulation of the medical professions in the Spanish empire, ed. J J TePaske, Durham, Duke University Press, 1985; and the most recent studies contained in Dynamis, 1996, 16.

${ }^{8}$ For an excellent survey, see José María López Piñero, 'Tradición y renovación en la medicina española del Renacimiento', in José María López Piñero (ed.), Viejo y nuevo continente: la medicina en el encuentro de dos mundos, Madrid, Laboratorios Beecham, 1992, pp. 35-90.

${ }^{9}$ Joseph Ewan, 'The Columbian discoveries and the growth of botanical ideas with special reference to the sixteenth century', in F Chiappelli (ed.), First images of America: the impact of the New World on the Old, 2 vols, Berkeley, University of California Press, 1976, vol. 2 , pp. $807-12$, p. 810 . 


\section{New World Materia Medica in Spanish Renaissance Medicine}

been little research into the ways in which American materia medica was distributed and assimilated into European medical practice. Jonathan Sauer, another scholar interested in the subject, after examining textual evidence, wrote that "many of the species were soon introduced, but acceptance there was another story". ${ }^{10}$ Charles Talbot went even further and even contradicted himself to some extent:

All in all, while the number of drugs discovered in the New World was considerable and while their importation into Europe enriched numerous merchants and druggists, their influence on European medicine was negligible. The reasons for this were mainly ignorance, conservatism and a lack of confidence on the part of the medical profession, and the exaggerated claims, sometimes wholly unfounded made by unscientific travellers and unscrupulous practitioners. ${ }^{11}$

It is well known that the Spaniards rejected the magico-religious context in which the plants were used by the indigenous people of America, and that they also insisted on incorporating these plants into the Galenic humoral system. Therefore, the argument goes, anything which did not fit or was not considered effective within the context of a set of empirico-rational judgements about bodily processes common to both "worlds" was rejected. ${ }^{12}$ Then too, important works on American plants such as the Codices of de la Cruz-Badiano and Bernardino de Sahagún, and Hernández's massive reports were, we are told, hidden in libraries for a long time and no one used their information. Both these circumstances prevented the introduction of new drugs and brought "little of truly lasting therapeutic value from the New World ... save for the four drugs [chinchona, ipecacuana, cocaine and curare] that achieved prominence only 150 years or more after Columbus first visited the Americas". ${ }^{13}$

New research has thrown doubt on this view, which I believe was too influenced by the expectation of finding out-in the process of assimilation of a new armamentarium-events which seemed significant from the perspective of modern medicine. ${ }^{14}$ This paper, although sometimes in a tentative way, aims to reconsider various sources, and will explore some aspects of the assimilation of American drugs into sixteenth-century medical theory, and look at their practical impact between 1492 and 1600. First, it will look at information relating to American drugs contained in printed texts; then it will consider the distribution and use of these medicinal

\footnotetext{
${ }^{10}$ Jonathan D Sauer, 'Changing perception and exploitation of the New World plants in Europe, 1492-1800', in Chiappelli (ed.), op. cit., note 9 above, pp. 813-32, p. 816.

${ }^{11}$ Charles H Talbot, 'America and the European drug trade', in Chiappelli (ed.), op. cit., note 9 above, p. 833-44, p. 841 .

${ }^{12}$ Guenter B Risse, 'Transcending cultural barriers: the European reception of medicinal plants from the Americas', in W-H Hein (ed.), Botanical drugs of the Americas in the Old and New Worlds, Stuttgart, Wissenschaftliche Verlagsgesellschaft, 1984 , pp. $31-42$, on p. 39; Anthony Grafton et al. 'Drugs and diseases: New World biology and Old World learning', in idem, New worlds, ancient texts: the power of tradition
}

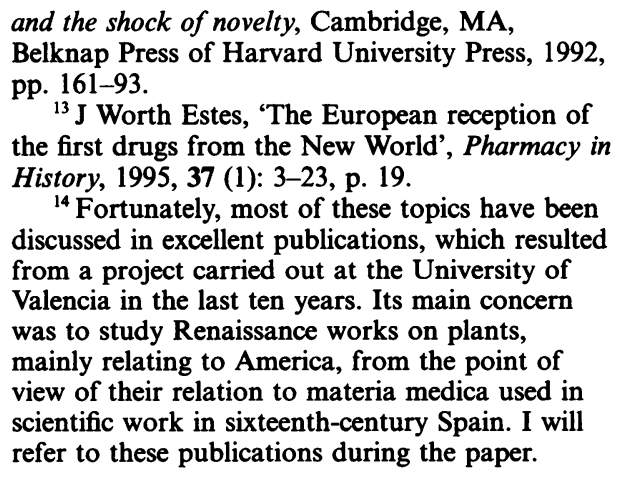
the first drugs from the New World', Pharmacy in History, 1995, 37 (1): 3-23, p. 19.

${ }^{14}$ Fortunately, most of these topics have been discussed in excellent publications, which resulted from a project carried out at the University of Valencia in the last ten years. Its main concern was to study Renaissance works on plants, mainly relating to America, from the point of view of their relation to materia medica used in scientific work in sixteenth-century Spain. I will refer to these publications during the paper. 


\section{Teresa Huguet-Termes}

plants, particularly among semi-educated or uneducated social groups, focusing on those drugs which were most used.

Here, with the subject of this paper in mind, I think two points are worth stressing: the first relates to the criticism of sources which I have used. In trying to assess the impact of American drugs at the different levels of medical practice a problem arises: the question of what is and what is not American. Sometimes the nomenclature of the new plants was similar to that of plants imported from the East and this makes identification difficult. To sort this problem out I have not attempted attributing American origins to materials if they were not accompanied with good enough descriptions and accompanying comments. Secondly, regarding one of the sources I have used-the inventories of apothecaries-I am aware that it would have been desirable to have had a larger series. However, the publications of archival material which exist do not make this possible. Although only partial, this information has none the less enabled me to support my hypothesis. Regarding the identification of botanical species, I have mainly relied on the work of earlier researchers in whose writings more specialized sources may be found. When possible, I have included the Spanish as well as the Náhuatl names of the plants.

The main sources of information on the early assimilation of and trade in American drugs are the works of the early conquistadores and other reports. ${ }^{15}$ Christopher Columbus (1452-1506) and Pedro Mártir de Anglería (1457-1526) have already been mentioned, and Gonzalo Fernández de Oviedo (1478-1557), who spent much time in the Americas between 1514 and 1557, published an extremely interesting work on natural history. ${ }^{16}$ As early as 1515 he described how guaiacum (guayaco) ${ }^{17}$ was preserved during the long Atlantic crossing. ${ }^{18}$ Other drugs exported to Spain during the early years of the sixteenth century and mentioned in texts of both the early chroniclers and other writers are: tobacco (tabacolquáuhyetl or picietl) ${ }^{19}$ from the very earliest days $;^{20}$ purgative nuts (avellanas purgativas/quauhyouachtli) ${ }^{21}$ from $1513,{ }^{22}$ and canafistula (cañafistola) ${ }^{23}$ and the new balsam (bálsamo de Nueva Españalhoitziloxitl) ${ }^{24}$ from

${ }^{15}$ A survey may be found in José Pardo Tomás, María Luz López Terrada, Las primeras noticias sobre plantas americanas en las relaciones de viajes y crónicas de Indias (1493-1553), Universitat de Valencia, CSIC, 1993, pp. 71-4.

${ }^{16}$ Gonzalo Fernández de Oviedo, De la natural hystoria de las Indias, Toledo, Ramón de Petras, 1526, and idem, La historia general de las Yndias, Seville, Juan Cromberger, 1535. For this paper I have used the 1851-1855 edition of his works: Historia general y natural de las Indias, Islas y Tierra firme del mar Oceano, 4 vols, Madrid, Real Academia de la Historia.

${ }^{17}$ Guaiacum officinale L. or Guaiacum sanctum L. See José Pardo Tomás and María Luz López Terrada, 'Repertorio de las plantas citadas en las fuentes analizadas. Identificación y sinonimia', in Pardo Tomás, López Terrada, op. cit., note 15 above, pp. 255-324, p. 290.

${ }^{18}$ Fernández de Oviedo, op. cit., note 16 above, vol. 1, p. 364 .
${ }^{19}$ Nicotiana tabacum L. or Nicotiana rustica $\mathbf{L}$. See Pardo Tomás, López Terrada, op. cit., note 17 above, p. 317.

${ }^{20}$ José María López Piñero, 'Nicolás Monardes: el estudio de la materia médica americana desde Sevilla', in José María López Piñero (ed.), Medicinas, drogas y alimentos vegetales del nuevo mundo: textos e imágenes españolas que los introdujeron en Europa, Madrid, Ministerio de Sanidad y Consumo, 1992, pp. 111-97, p. 121.

${ }^{21}$ Jatropha multifida L. or Curcas multifudus Endl. See López Piñero, 'Nicolás Monardes', op. cit., note 20 above, p. 132.

${ }^{22}$ Fernández de Oviedo, op. cit., note 16 above, vol. 1, p. 369.

${ }^{23}$ Cassia grandis L. See Pardo Tomás, López Terrada, op. cit., note 17 above, p. 272.

Fernández de Oviedo, op. cit., note 16 above, vol. 1, p. 553 . 


\section{New World Materia Medica in Spanish Renaissance Medicine}

1515. ${ }^{25}$ According to Nicolás Monardes (c. 1493-1588), Mechoacan root, or white jalap (raiz de Mechoacan/tecuache) ${ }^{26}$ had arrived by $1540,{ }^{27}$ sarsaparilla (zarzaparrillal mecapatli or quauhmecapatli) $)^{28}$ by $1545,{ }^{29}$ and it appears from the Sevillian archives that liquid amber (liquidámbarlocozotl) ${ }^{30}$ was being imported by $1542 .{ }^{31} \mathrm{I}$ will now look at how some of these drugs were described in a selection of medical texts.

\section{American Drugs in Medical Texts}

One of the most important works published by a member of the medical élite at that time was Andrés Laguna's translation and commentary on Dioscorides's Materia medica. ${ }^{32}$ Laguna (c. 1510-1559) was a representative of the humanist Galenism that existed in Spain in that period. His work is an example of how scholars, in trying to expand their knowledge of natural history, devoted much of their efforts simply to identifying plants, whether from the old world or the new, that Dioscorides had included in his book compiled around $70 \mathrm{AD}$. Laguna's commentary was first published in Antwerp in 1555 and by the end of the eighteenth century had been reprinted twenty-two times.

Although the number of American plants Laguna included was small, ${ }^{33}$ his references were explicit enough to show that American drugs were taken very seriously when no similar drugs were available for common illnesses or when they were associated with the healing of new and dangerous diseases. He included among new plants only those that were absolutely necessary to cover therapeutic needs. He did not discard American plants from a theoretical point of view, he simply thought that not all of them were necessary. By contrast, those he did list, he fitted into the Galenic system as substitutes for plants described by Dioscorides that Laguna thought had disappeared, or if he could not do this, he called them gifts from God.

\footnotetext{
${ }^{24}$ Different varieties of goaconax (Croton sp.) and Myroxylon balsamum (L.) Harms. See Pardo Tomás, López Terrada, op. cit., note 17 above, $p$. 266.

${ }^{25}$ Fernández de Oviedo, op. cit., note 16 above, vol. 1, p. 367.

${ }^{26}$ Convolvulus mechoacan Vandelli or Convolvulus orizabensis Pellet, López Piñero, 'Nicolás Monardes', op. cit., note 20 above, p. 135.

${ }^{27}$ Nicolás Monardes, Dos libros, el uno que trata de todas las cosas que traen de nuestras Indias occidentales, que sirven al uso de la medicina y como se ha de usar la rayz de Mechoacan, purga excelentisima. El otro libro, trata de las medicinas maravillosas que son contra todo veneno, la piedra Bezoar, y a yerva Escuerconera, Seville, Sebastián Trujillo, 1565, fol. $53 \mathrm{v}$.

${ }^{28}$ Smilax medica Schecht et Cham. from Mexico and Honduras or Smilax officinalis Humb. and Smilax syphilitica from Quito and Guayaquil about which Monardes wrote in the
}

second part of his work. See Pardo Tomás, López Terrada, op. cit., note 17 above, p. 324 .

${ }^{29}$ Monardes, op. cit., note 27 above, fol. 33v.

${ }^{30}$ Liquidambaris styraciflua L. Pardo Tomás, López Terrada, op. cit., note 17 above, p. 308.

${ }^{31}$ According to Mercedes Fernández-Carrión and José Luis Valverde, 'Research note on Spanish-American drug trade', Pharmacy in History, 1988, 30 (1): 27-32, p. 29.

${ }^{32}$ Andrés Laguna, Pedacio Dioscorides Anazarbeo, acerca de la materia medicinal, y de los venenos mortiferos, traducido de la lengua griega en la vulgar castellana, e illustrado con claras y substanciales annotationes y con las figuras de innumeras plantas exquisitas y raras, Salamanca, Mathias Gast, 1566, reprinted in Madrid, Instituto de España, 1968.

${ }^{33}$ José Luis Fresquet Febrer, 'Terapéutica y materia médica americana en la obra de Andrés Laguna (1555)', Asclepio, 44: 53-82, p. 82, and Enrique Alvarez López, 'Las plantas de América en la botánica europea del siglo XVI', Revista de Indias, 1945, 19-22: 221-88, p. 264. 


\section{Teresa Huguet-Termes}

An example of this is the balsam that Dioscorides had described but which could not be found nor identified. Laguna did not hesitate to include an explicit reference to the New Spain balsam in his commentary, giving it the virtue (gracia) of being a more useful substitute than the "real one", probably meaning an Eastern substitute. He stated that it was wonderful for many ailments, referring to it as a sovereign remedy. ${ }^{34}$

Another drug he mentioned was estoraque from New Spain, which he identified as the unique substitute of the Storax Styracinus mentioned by Dioscorides. ${ }^{35}$ Perhaps the reason for the prominent place which Laguna gave to new balsam and estoraque was the unavailability of other substitutes. This seems not to have been the case with frankincense, terebinth, gum and sandalwood (surprisingly the Portuguese provided sandalwood in large quantities ${ }^{36}$ ) for which substitutes would have been easy to find in the rare event of the "real plants" not being available.

So, for example, we might argue that Laguna did not make any mention of purgative nuts, canafistula, fig tree of hell oil (higuera del infiernolquauhayohuachtli), ${ }^{37}$ all purgatives found in the New World, because there were plenty of other well-known purgatives such as Ricinus and rhubarb in Europe.

The way in which Laguna wrote about guaiacum and sarsaparilla shows that they had already been assimilated into the Galenic medical system as "new medicines" for "new diseases", mainly the great pox. ${ }^{38}$ The Christian belief that God supplied the remedies for diseases may well have influenced their quick assimilation, at both theoretical and practical levels. Laguna saw guaiacum, in particular, as a remedy that should not be criticized, and from the very beginning élite physicians felt confident about using it. Commenting on sarsaparilla and China root (raiz de China) ${ }^{39}$ Laguna wrote, "It is true that at first, before these plants were understood, as the world loves novelties, they were greatly sought after, especially that called China". ${ }^{40}$ It seems that Laguna believed that a knowledge of the action of these plants was necessary before they could be used.

Other sources for studying the scholarly reception of American drugs are the works by physicians who had a particular economic interest in plants of the New World and therefore wanted to promote them. Most historians discussing the early trade in medicinal plants mention Diego Alvarez Chanca (died c. 1515), who accompanied Columbus on his second expedition to America (1493), and was the first physician to take notice of and write about the new drugs, mainly from a financial point of view. ${ }^{41}$ Later, the first and most widespread account of American

${ }^{34}$ Laguna, op. cit., note 32 above, fol. 27.

${ }^{35}$ Ibid., fol. 49.

${ }^{36}$ Ibid., fol. 28.

${ }^{37}$ Jatropha curcas L. or Curcas purgans Endl. Pardo Tomás, López Terrada, op. cit., note 17 above, p. 295.

${ }^{38}$ Laguna, op. cit., note 32 above, fol. 83.

${ }^{39}$ Smilax pseudo-china L. López Piñero, 'Nicolás Monardes', op. cit., note 20 above, p. 137.

${ }^{40}$ Laguna, op. cit., note 32 above, fol. 83.

\footnotetext{
${ }^{41}$ E Lorenzo Sanz, Comercio de España con América en la época de Felipe II, 2 vols, Valladolid, Servicio de Publicaciones de la Diputación Provincial de Valladolid, 1979, vol. 1, p. 320; Juan Antonio Paniagua, 'Un médico europeo en el descubrimiento: Diego Alvarez Chanca', in López Piñero (ed.), op. cit., note 8 above, pp. 91-105, p. 94; Luciano Gallinari, Diego Alvarez Chanca: medico di Cristoforo Colombo, Cagliari, CNR, 1992, pp. 193-4.
} 


\section{New World Materia Medica in Spanish Renaissance Medicine}

drugs was that by Monardes. He published his book in Spanish, not Latin, in three parts $\left(1565,{ }^{42} 1571^{43}\right.$ and the complete work was published in $\left.1574^{44}\right)$. The English translation of 1577 by John Frampton was entitled The three bookes of joyfull newes out of the newe founde worlde. ${ }^{45}$ Once established in Seville, where Monardes lived from 1533 to 1588 , he became more and more interested in medicinal plants from the New World and even founded an import-export company with Juan Núñez de Herrera in 1553, which traded in many things, among them slaves and medicinal products. ${ }^{46}$ Although his interest in American drugs was mainly financial (he did become a very rich man), he has been seen as responsible for introducing many American drugs to the European medical world as his book was very quickly translated into Latin, Italian, English, German and French. ${ }^{47}$ In it he described and commented on the uses of about 100 American drugs. ${ }^{48}$

The question is: can we speak of a true scholarly acceptance on the basis of a book written in the vernacular by a millionaire physician with a great economic interest in American drugs? Juan Fragoso (c. 1530-1597), a Latinate surgeon, doubted this in his Discursos de las cosas aromaticas published in $1572 .{ }^{49} \mathrm{He}$ repeatedly described Monardes' book as propaganda, saying, for instance, about fig tree of hell oil, that "since Spain had plenty of that medicinal plant of its own it was unnecessary to bring more from the New World and speak about it as if it were rare", ${ }^{50}$ meaning that those who wrote about these exotic plants were promoting them unnecessarily. Similarly, the physician Clusius (Charles de L'Écluse, 1526-1609), who was interested in American drugs and corresponded with Sevillian physicians such as Juan de Castañeda and Simón de Tovar, and even Juan Plaza in Valencia, did not, as far as we know, get in touch with Monardes; although Monardes, on the other hand, did have contacts with other European physicians, giving them information on, for

\footnotetext{
${ }^{42}$ Monardes, op. cit., note 27 above.

${ }^{43}$ Nicolás Monardes, Segunda parte del libro, de las cosas que traen de nuestras Indias occidentales que sirven al uso de la medicina. Do se trata del tabaco, y de la sassafras: . . y de muchas yervas y plantas simientes y licores: que agora han venido de aquellas partes, de grandes virtudes y maravillosos efectos, Seville, Alonso Escrivano, 1571.

${ }^{44}$ Nicolás Monardes, Primera y segunda y tercera partes de la historia medicinal de las cosas que se traen de nuestras Indias occidentales, que sirven en medicina, Seville, Alonso Escrivano, 1574.

${ }^{45}$ John Frampton, The three bookes of joyfull newes out of the newe founde worlde written in the Spanishe tongue ... translated into Englishe by John Frampton, Merchant, London, by William Norton, 1577. This work was reprinted in 1580 and 1596. Quotations in the paper are from John Frampton, Joyfull newes out of the newe founde worlde... written in Spanish by Nicholas Monardes ... with an introduction by Stephen
}

Gaselee, 2 vols, London, Constable, 1925.

${ }^{46} \mathrm{~F}$ Rodríguez Marín, La verdadera biografia del Doctor Nicolás Monardes, Madrid, Tip. de la Revista de Archivos, 1925, p. 25. For an interesting biography, see Francisco Guerra, Nicolás Bautista Monardes: su vida y su obra (ca. 1493-1588), Mexico, Compañía Fundidora de Fierro y Acero de Monterrey, 1961.

${ }^{47}$ José María López Piñero, María Luz López Terrada, 'El tratado de Monardes: acogida y primeras traducciones', in idem, La influencia española en la introducción en Europa de las plantas americanas (1493-1623), Universitat de Valencia, CSIC, 1997, pp. 55-66.

${ }^{48}$ José María López Piñero, 'Las "nuevas medicinas" americanas en la obra (1565-1574) de Nicolás Monardes', Asclepio, 1990, 42: 3-68.

49 Juan Fragoso, Discursos de las cosas aromaticas, arboles y frutales, y de otras muchas medicinas simples que se traen de la India oriental, $y$ sirven al uso de medicina, Madrid, Francisco Sánchez, 1572.

${ }^{50}$ Ibid., fol. $87 \mathrm{v}$. 


\section{Teresa Huguet-Termes}

example, Mechoacan $\operatorname{root}^{51}$ and tacamahaca (tacamahacaltecomahaca) ${ }^{52}$ But his book was translated into Latin in 1574 by Clusius ${ }^{53}$ and also widely read by high ranking physicians, ${ }^{54}$ so it does need to be seriously considered as an important step in the scholarly assimilation of American drugs.

The success of Monardes' work all over Europe raised people's expectations of the medical and scientific value of American plants and this led Philip II in 1570 to send Francisco Hernández (1515-87) to America to study the flora and the fauna. Hernández moved in the medical circles of the Spanish court and was well trained for such a mission. Philip II saw an opportunity to exploit the natural resources of his empire. ${ }^{55}$

The results of Hernández's expedition included living plants, planted in barrels and pots, "sixty-eight sacks of seeds and roots", paintings of plants and animals on pine panels, and thirty-eight volumes containing paintings and texts. ${ }^{56}$ Some historians have asserted that Hernández's manuscripts had little impact on scholarly medicine in the sixteenth century, ${ }^{57}$ but I am more inclined to agree with López Piñero and Pardo Tomás who have recently put forward a different theory. ${ }^{58}$ According to them, although a resumé of Hernández's works made by Nardo Antonio Recchi, at the request of Philip II, was not distributed until $1651,{ }^{59}$ information from the manuscripts and reports of the expedition circulated widely, and we know that many important physicians such as Francisco Valles, Ulisse Aldrovandi, Joachim Camerarius and many others had a look at them. ${ }^{60}$ In fact, in 1580, Philip II appointed Recchi court physician with the primary responsibility of studying the materials of Hernández and of making a selection of the plants most valuable from a healing point of view. Among the 400 selected plants we find all the American drugs that were relevant in the expansion of the therapeutic "arsenal" in European medicine from the late Renaissance to the Baroque period. ${ }^{1}{ }^{1}$ Further, Francisco Ximénez, the Dominican doctor, published in Mexico a translation into Spanish of Recchi's selection in $1615 .{ }^{62}$ We must consider seriously that Hernández's materials had circulated in manuscript

${ }^{51}$ Monardes, op. cit., note 27 above, fol. 30v.

${ }^{52}$ Elaphrium tecomaca (D.C.) Standl. López Piñero, 'Nicolás Monardes', op. cit., note 20 above, p. 128. See G Muratori, 'Una relazione autografa del medico spagnolo Monardes sulla tecamahaca', Pagine di Storia della Medicina, 1964, 8: 28-35.

${ }^{53}$ Nicolás Monardes, De simplicibus medicamentis ex occidentali India delatis quorum in medicina usus est, interprete Carolo Clusio Atrevate, Antwerp, Christopher Plantin, 1574.

${ }^{54}$ José Pardo Tomás, 'Obras españolas sobre historia natural y materia medica americanas en la Italia del siglo XVI', Asclepio, 1991, 43: 51-94.

${ }^{55}$ José María López Piñero, Ciencia y técnica en la sociedad española de los siglos XVI y XVII, Barcelona, Labor Universitaria, 1979, pp. 287-8.

${ }^{56}$ José María López Piñero, The Pomar codex (ca. 1590): plants and animals of the old world and from the Hernández expedition to America, Florence, Leo S Olschki, 1992, p. 42.
${ }^{57}$ José Maria López Piñero, José Pardo Tomás, Nuevos materiales y noticias sobre la historia de las plantas de Nueva España de Francisco Hernández, Universitat de Valencia, CSIC, 1994, pp. 11-15.

${ }^{58}$ Ibid.

${ }^{59}$ Rerum medicarum Novae Hispaniae thesaurus, seu, plantarum, animalium, mineralium Mexicanorum historia ex Francisci Hernandez ... in ipsa Mexicana urbe conscriptis a Nardo Antonio Reccho ... collecta ac in ordinem digesta, Rome, V Mascardi, 1651.

${ }^{60}$ López Piñero, Pardo Tomás, op. cit., note 57 above, p. 71-2.

${ }^{61}$ Ibid., pp. 59 and 70.

${ }^{62}$ Francisco Ximénez, Quatro libros de la naturaleza, $y$ virtudes de las plantas, $y$ animales que estan recevidos en el uso de la medicina en la Nueva España, Mexico, Widow of López Dávalos, 1615. 


\section{New World Materia Medica in Spanish Renaissance Medicine}

form, as Recchi's and Ximénez's texts contained the plants from Hernández's studies that were most interesting from a practical point of view. The manuscript materials of Hernández also influenced the content of the Pomar Codex (c. 1590). The Codex contains 218 colour paintings of fauna and flora, which Philip II presented to Jaime Honorato Pomar (1550-1606) who held the chair of simple medicines at the University of Valencia. The Pomar Codex contains drawings of twenty-five plants from the New World.$^{63}$ One can identify the plants that grew in the royal gardens by the style of the pictures. Those painted from nature have a "Florentine" style similar to the work of Jacopo Ligozzi, while those copied from the volumes of Hernández retain the schematic quality peculiar to native American artists. ${ }^{64} \mathrm{~A}$ few of the New World plants in the Pomar Codex were not included in Hernández's works ${ }^{65}$ and may have reached Spain by another way.

The other manuscripts often believed to have had no influence on sixteenthcentury medicine are the Codex of Martín de la Cruz and Juan Badiano (1552) ${ }^{66}$ and the Florentine Codex (1578-80) by Bernardino de Sahagún. Regarding the first, it is worth noting that Monardes made an intriguing reference to "the greate effectes" of Mechoacan root that "the Indians dooeth publishe". ${ }^{67}$ If this is a reference to a book of some sort, the only "publication" he could have known in 1565 was the Codex de la Cruz-Badiano. Bearing in mind his close links with Francisco de Mendoza, ${ }^{68}$ who gave it to the king in $1553,{ }^{69}$ he may well have seen it. Regarding the Sahagún Codex, a study by $\mathrm{P}$ Galluzzi ${ }^{70}$ shows that although it was not published, it did influence learned medicine. ${ }^{71}$ We know that Ulisse Aldrovandi had heard of its contents from Girolamo Mercuriale, who had studied it, and that Aldrovandi tried to see the Codex, then held by the Medici. ${ }^{72}$ So $\mathrm{J}$ Worth Estes may be wrong when he says that "The immense amount of information about New World drugs that Hernández collected was, like that of De la Cruz and Sahagún, unknown to Europeans in the first century after the conquest of Mexico". ${ }^{73}$

Another physician interested in the new plants was the Galenist Luis Mercado

${ }^{63}$ López Piñero, op. cit., note 56 above, p. 48.

${ }^{64}$ Ibid., p. 51.

${ }^{65}$ Ibid., p. 49.

${ }^{66}$ Libellus de medicinalibus indorum herbis,

1552. See Carlos Viesca Treviño, 'El códice de la Cruz-Badiano, primer ejemplo de una medicina mestiza', in José Luis Fresquet Febrer, José María López Piñero (eds), El mestizaje cultural y la medicina novohispana del siglo XVI, Universitat de Valencia, CSIC, 1995. See also Emily Walcott Emmart, The Badianus manuscript: (Codex Barberini, Latin 241) Vatican Library: an Aztec herbal of 1552, introduction and translation, Baltimore, John Hopkins Press, 1940.

${ }^{67}$ Monardes, op. cit., note 27 above, fol. 55r-56v; Frampton, op. cit., note 45 above, vol. 1, p. 58.

${ }^{68}$ Monardes, op. cit., note 27 above, fol. 29r.

${ }^{69}$ Viesca Treviño, op. cit., note 66 above, $p$. 75. Later, the Codex of 1552 was copied at the request of Cassiano dal Pozzo and used by members of the Accademia dei Lincei in the early seventeenth century. The copy is at Windsor Castle. I am grateful to Simon Varey for this information.

${ }^{70} \mathrm{P}$ Galluzzi, La renascita de la sciencia, Florence, Edicioni Medicee, 1980.

${ }^{71}$ Until now the account that has circulated is summed up by the words of Worth Estes, op. cit., note 13 above, p. 4, "Although intended as a gift to Charles V, the manuscript disappeared into first one library and then another after it arrived in Europe", "thus it could have exerted no influence on European medicine in the 16th century".

${ }^{72}$ José María López Piñero, José Pardo Tomás, La influencia de Francisco Hernández (1515-1587) en la constitución de la botánica y la materia médica modernas, Universitat de Valencia, CSIC, 1996, p. 132.

${ }^{73}$ Worth Estes, op. cit., note 13 above, p. 4. 


\section{Teresa Huguet-Termes}

(c. 1525-1611). ${ }^{74}$ In his Consultationes morborum published posthumously ${ }^{75}$ he mentioned several, among them guaiacum ${ }^{76}$ and China root. ${ }^{77} \mathrm{He}$ also listed sassafras (sassafrás) ${ }^{78}$ and sarsaparilla, ${ }^{79}$ usually mixing all these drugs with old remedies ${ }^{80}$ So even such a conservative man had no problem in fitting these new drugs into the current medical system.

\section{The Impact of American Drugs on Medical Practice}

I have been discussing the scholarly view of these drugs. I would now like to look at how they were assimilated at a practical and domestic level.

Monardes described Seville as a great pharmaceutical market, listing several of the imported drugs. For instance, regarding liquid amber, he stated, "There is brought muche quantitie of liquid amber to Spaine ... to perfume in thinges of sweete smelles, wasting it in place of Storacke"81 and "There is knowen of this plaister verie greate experience, in this Citie, for the good effect that it doeth" ${ }^{82}$ It seems that trade continued until 1574 when Monardes again wrote, "There is brought muche quantitie of liquid amber to Spaine, in so muche that they doe bringe many Pipes, and Barelles full thereof to sell for Merchaundise." ${ }^{\text {"3 }}$ Monardes also referred to the use of balsam since the discovery of New Spain and to its arriving in large amounts, as well as its common use in Seville. ${ }^{84} \mathrm{He}$ may have exaggerated the last point. Pierre Chaunu has shown that between 1568 and 1619 at least 209 tons of canafistula (about two and a half million doses), 670 tons of sarsaparilla (about seven and a half million doses), and 930 tons of guaiacum (two and a half million doses) were brought into the port of Seville. ${ }^{85}$ One would therefore expect the city's apothecaries to have stocked many American drugs. But, extremely surprisingly, given that this city was the port of entry for all these therapeutic novelties, in the inventories of apothecaries in Seville from 1551 to 1609 $(1551,1570,1573,1609)^{86}$ there is very little mention of American drugs. Those that are listed are canafistula (20 lbs, enough for preparing eighty doses) and Mechoacan root, which appear in two inventories of $1570 ;{ }^{87}$ sarsaparilla $(3 \mathrm{lbs}$, enough for twelve

\footnotetext{
${ }^{74}$ Juan Riera Palmero, Vida y obra de Luis Mercado, Universidad de Salamanca, 1968.

${ }^{75}$ Luis Mercado, Consultationes morborum complicatorum, \& gravissimorum: cum disputationibus necessariis ad naturam cuiusque morborum capessendam, praesagium, et curationem, Frankfurt, Collegio Musarum Paltheniano, 1614.

${ }^{76}$ Ibid., fols. 3, 7, 11, 33, and 93.

${ }^{77}$ Ibid., fols. 3, 7 and 8 .

${ }^{78}$ Ibid., fols. 11, 7, 33, and 97. (Sassafras albidum (Nutt.) Ness), Pardo Tomás and López Terrada, op. cit., note 17 above, p. 232.

${ }^{79}$ Mercado, op. cit, note 75 above, fol. 7 .

${ }^{80}$ Ibid., fol. 111, we usually find them mixed. The resulting compound was called Aqua stillotica and was used to promote sweating. In fols. 38,57 and 66, a mixture of guaiacum and
}

China root appears.

${ }^{81}$ Monardes, op. cit., note 27 above, fol. $15 v$; Frampton, op. cit., note 45 above, vol. 1, p. 20.

${ }^{82}$ Monardes, op. cit., note 27 above, fol.15v; Frampton, op. cit., note 45 above, vol. 1, p. 21.

${ }^{83}$ Monardes, op. cit, note 27 , fol. $17 \mathrm{v}$; Frampton, op. cit., note 45 above, p. 20.

${ }^{84}$ Monardes, op. cit., note 27 above, fol. $17 \mathrm{v}$ and $20 \mathrm{v}$.

${ }^{85}$ Huguette Chaunu and Pierre Chaunu, Séville et l'Atlantique (1504-1650), 8 vols, Paris, A Colin, 1955-9, vol. 2, pp. 1022, 1023, 1025, 1027.

${ }^{86}$ Mercedes Fernández-Carrión, José Luis Valverde, Farmacia y sociedad en Sevilla en el siglo XVI, Seville, Servicio de Publicaciones del Ayuntamiento de Sevilla, 1985, pp. 80-96.

${ }^{87}$ Ibid., pp. $80-1$. 


\section{New World Materia Medica in Spanish Renaissance Medicine}

doses) in the form of syrup in an inventory of $1573,{ }^{88}$ fig tree of hell oil in $1570,{ }^{89}$ and something similar happens at the hospital for the great pox at Valencia. Although there are significant references to guaiacum and sarsaparilla being used by hospital physicians, ${ }^{90}$ these drugs do not appear in the inventories of hospital apothecaries, and physicians continued throughout the century to treat patients with mercurials. ${ }^{91}$

American drugs are also seldom listed in the official pharmacopoeias that appeared in Spain in the sixteenth century and which established the rules for stocking and preparing remedies. Taking the example of the later editions of the pharmacopoeias of Barcelona (1587) ${ }^{92}$ and Valencia (1601), ${ }^{93}$ I found that the Barcelona one contains little reference to American drugs, and when these are mentioned it is as substitutes for Eastern products. By contrast, in the Valencian pharmacopoeia of 1601 four American drugs are listed: new balsam, canafistula, guaiacum and tacamahaca. ${ }^{94}$

If we look at the work of Latinate surgeons, we find more contradictory references concerning new drugs. These men practised the medicine learned at universities. Nevertheless, they were closer to the ordinary people than the élite physicians were, although still much influenced by the latter. American drugs are hardly found in the antidotaries of the surgical treatises by Latinate surgeons. ${ }^{95}$ However, the Latinate surgeon Juan Fragoso, in his Discursos de las cosas aromaticas que vienen de las Indias Orientales, which dealt with Indian and Oriental drugs, surprisingly also mentioned many American drugs. He described the results of many experiments with anime (anime), ${ }^{96}$ tacamahaca, ${ }^{97}$ and, as a remedy for injuries, tobacco, ${ }^{98}$ saying that "The effect of Aceite de Aparicio has been forgotten because of the knowledge of this new drug". 99 This indicates again the practical impact and use at that time.

But these relatively infrequent listings point to a major problem. Where did they all go, those vast quantities of drugs, constituting millions of potential doses, that Chaunu has demonstrated were imported to Spain?

Since, at that time, Seville was full of merchants from Genoa, France, England,

${ }^{88}$ Ibid., pp. 88-9.

${ }^{89}$ Ibid., p. 86.

${ }^{90}$ For example, that of the Latinate surgeon Juan Calvo who said that "in spring and autumn not only the unction but also guaiacum water and sarsaparilla and sweating gave great profit", quoted in María Luz López Terrada, 'El tratamiento de la sífilis en un hospital renacentista: la sala del mal de siment del Hospital General de Valencia', Asclepio, 1989, 41 (2): 19-50, on p. 31.

${ }^{91}$ Ibid., p. 33. For complementary bibliography about the uses of guaiacum in the treatment of the great pox, see Robert S Munger, 'Guaiacum, the holy wood from the New World', J. Hist. Med. Allied Sci., 1949, 4: 196-229; and Jon Arrizabalaga, John Henderson and Roger French, The great pox: the French disease in Renaissance Europe, New Haven and London, Yale University Press, 1997.

${ }^{92}$ Concordia Pharmacopolarum Barcinonensium, Barcelona, Huberto Gotard, 1587.
${ }^{93}$ Officina medicamentorum, 1601, I have used the edition prepared by José Maria Suñé, Officina medicamentorum. Introducción y comentarios, Barcelona, Cátedra de Historia de la Farmacia y Legislación Farmacéutica, 1973.

${ }^{94}$ I have used the alphabetical list of simple drugs mentioned in Pedro Vernia, La farmacopea valenciana, Burriana, Sp., 1981, on pp. 57, 60, 70, 81.

${ }^{95}$ José Luis Fresquet Febrer, 'Los inicios de la asimilación de la materia médica americana por la terapéutica europea', in López Piñero (ed.), op. cit., note 8 above, pp. 281-309, p. 303.

${ }^{96}$ Hymenae courbaril L. and related species. Pardo Tomás, López Terrada, op. cit., note 17 above, on p. 262. See Fragoso, op. cit., note 49 above, fol. $17 \mathrm{v}$.

${ }^{97}$ Fragoso, op. cit., note 49 above, fol. 19v.

${ }^{98}$ Ibid., fol. $145 \mathrm{v}$.

${ }^{99}$ Ibid., fol. $49 \mathrm{v}$. 
and Germany, ${ }^{100}$ one possibility could be that American drugs were quickly exported after arrival. It is true that the role of merchants and some physicians in the importation of new plants into Italy allowed physicians, such as Ulisse Aldrovandi, who were interested in American plants, to acquire them, ${ }^{101}$ and that the main promoters of Monardes' translations in Europe were merchants, such as Frampton for England (1577), ${ }^{102}$ or apothecaries with good business sense such as Antoine Colin for France (1602). ${ }^{103}$ Nevertheless, we have very little evidence of private companies founded to deal in American drugs in large amounts. For instance, we know that by the end of 1530 Giovanni Battista Ramusio and Fernández de Oviedo had signed an agreement to establish a company trading in American products, funded by the Venetian merchant Antonio Priuli. But we do not have any evidence that their company actually exported American drugs to Italy. ${ }^{104}$ As for England, R S Roberts ${ }^{105}$ says that there is no evidence of large amounts of drugs being imported before Frampton's translation of Monardes' book in 1577, or even during the sixteenth century as a whole. Evidence of this is the fact that only sarsaparilla, sassafras wood, tobacco, Mechoacan root and guaiacum are included in the inventory of an Exeter apothecary of $1596 .{ }^{106}$ Very few New World drugs appear in drug inventories contained in the wills of sixteenth-century French physicians, ${ }^{107}$ and, as far as Germany is concerned, only two recipients of American drugs (balsam and tacamahaca) are found in the Fuggers' inventory of $1601 .{ }^{108}$ Nevertheless, Fragoso's

\footnotetext{
${ }^{100}$ For a survey of communications, foreign trade and relations with the Indies, see John Lynch, Spain 1516-1598: from nation state to world empire, Oxford, Blackwell, 1998 reprint, pp. $184-217$.

${ }^{101}$ López Piñero, Pardo Tomás, op. cit., note 72 above, p. 132.

${ }^{102}$ Frampton, op. cit., note 45 above.

${ }^{103}$ Nicolás Monardes, 'Histoire des simples medicamens apportés des terres neuves, desquels on se sert en la medecine. Escrite premierement en Espagnol ... Du depuis mise en Latin, et illustrée de plusieurs annotations par Charles Clusius d'Arras. Et nouvellement traduicte en françois par Anthoine Colin', in Histoire des drogues, espiceries, et de certains medicaments simples, qui naissent és Indes, tant orientales que occidentales, divisée en deux parties, Lyons, Jean Pillehotte, 1602, p. 503-720.

${ }^{104}$ José Pardo Tomás, 'Obras españolas sobre historia natural y materia médica americanas en la Italia del siglo XVI', Asclepio, 1991, 43: 51-84, on p. 65.

${ }^{105} \mathrm{R}$ S Roberts, 'The early history of the import of drugs into Britain', in F N L Poynter (ed.), The evolution of pharmacy in Britain, London, Pitman Medical, 1965, pp. 165-85, p.168. It should be pointed out that Roberts' essay is quite old and recent research led me to think that the subject should be reconsidered, see
}

Simon Varey and Rafael Chabrán, 'Mexican medicine comes to England', Viator, 1995, 26: 352-3. I am also grateful to Simon Varey for letting me read the manuscript of his chapter 'Hernández in the Netherlands and England', from Searching for the secrets of nature: the life and works of Dr Francisco Hernández, ed. Simon Varey, Rafael Chabrán, and Dora B Wiener, Stanford University Press, 2000, which in my view throws serious doubts on Roberts' conclusions from the examination of related and new materials.

${ }^{106}$ Margery Rowe and G E Trease, 'Thomas Baskerville, Elizabethan apothecary of Exeter', Trans. Br. Soc. Hist. Pharm., 1970, 1 (1): 3-28, on p. 9 .

${ }^{907}$ Françoise Lehoux, Le cadre de vie des médecins parisiens aux XVI et XVIIe siècles, Paris, A and J Picard, 1976.

${ }^{108}$ Annette Zimmermann, 'Pharmazeutisches aus dem Nachlassinventar des Octavianus Secundus Fugger (1549-1600)', Beitrage zur Geschichte der Pharmazie, 1981, 31 (12): 89-91, on p. 90. I would like to mention here the comment made during the symposium by $\mathrm{Dr}$ Annemarie Kinzelbach (University of Heidelberg) that guaiacum was used in the Augsburg Hospital during the sixteenth century. It would be interesting to know where that guaiacum came from. 


\section{New World Materia Medica in Spanish Renaissance Medicine}

report that "such great quantities of canafistula are now being brought in laden vessels from those lands that there is sufficient to supply not only Spain, but all Europe and even the Levant", ${ }^{109}$ should make us think more about this first possibility.

Was a great demand for new healing tools the reason why apothecaries' stocks were quickly used up, and does this also explain the absence of American drugs in Sevillian pharmacies? This is very unlikely in my view, because, even assuming a great demand, not all the apothecaries could have coped with it. We must bear in mind that those apothecaries who wanted to trade in American drugs became "associated" like the rest of the traders. Within the system of Atlantic commerce between Spain and America, associations were based on private companies. They were directed by a limited group of contractors and individuals, under government rules. These associations consisted of physicians, surgeons, apothecaries and merchants. ${ }^{110}$ Also included were ships' masters, officers of the Casa de Contratación and notaries of the Inquisition. ${ }^{11}$ All these people, as well as the apothecaries, could sell these drugs. The trade in American drugs seems to have been chiefly in the hands of certain rich apothecaries such as Bernardino de Burgos, ${ }^{112}$ the Arigon and the Arenzano families, who, as the inventories demonstrate, ${ }^{113}$ had links with certain physicians such as Monardes or with the crown or a privileged place in the overland trade. Not surprisingly, the Sevillian apothecaries' lists in which American drugs appear belonged to men like Juan de Luzio who traded with America. His inventory dating from 1570 contains canafistula, white jalap and fig tree of hell oil. ${ }^{114}$ Also, sarsaparilla is listed in the 1573 inventory of Alonso de Mendoza, a merchant of Seville who sold an apothecary's business to Alonso de Aguilar from Lucena. ${ }^{115}$ Yet in an inventory of a pharmacy in Madrid made in 1570, practically the same American drugs were listed as in the inventories of Sevillian pharmacies, that is: canafistula and Mechoacan root. ${ }^{116}$ American drugs in apothecaries' shops outside Andalusia also seem to have been concentrated in the hands of a few apothecaries, as two other cases in Valladolid ${ }^{17}$ and Barcelona ${ }^{118}$ demonstrate. An Italian anecdote illustrates this. A speziale from Verona, Francesco Calzolari, who enjoyed a privileged place

\footnotetext{
${ }^{109}$ Fragoso, op. cit., note 49 above, fol. 77 r.

110 José Luis Martínez, Pasajeros de Indias,

Madrid, Alianza, 1983, p. 146, quoted in

Fernández-Carrión, Valverde, op. cit., note 31

above, p. 29.

${ }^{111}$ Ibid., p. 29.

${ }^{112}$ López Piñero, op. cit., note 48 above, p. 18.

${ }^{113}$ José Luis Valverde, Carmen Sánchez Téllez,

'Juan, José y Rafael de Arigón, boticarios reales

(1544 47)', Ars Pharmaceutica, 1977, 18 (2):

217-58, p. 223, 225.

${ }^{114}$ Fernández-Carrión, Valverde, op. cit., note 86 above, pp. $72,80,81,86$.

${ }^{115}$ Ibid., pp. 48 and 88.

${ }^{116}$ The pharmacy belonged to the Royal

Apothecary, Diego de Burgos. See Pilar Herrero

Hinojo, 'Inventarios de farmacia', Boletín de la
}

\author{
Sociedad Española de Historia de la Farmacia, \\ 1968, no. 75, pp. 97-115, pp. 97, 104. \\ ${ }^{117}$ In the 1595 inventory of the apothecary- \\ merchant Lucas de Barcena are listed carana, \\ coca and tacamahaca. See Félix Francisco Pastor \\ Frechoso, Boticas, boticarios y materia médica en \\ Valladolid (siglos XVI-XVII), Salamanca, Junta \\ de Castilla y León, 1993, pp. 149 and 153. \\ ${ }^{118}$ Nine drug inventories from Barcelona \\ between 1503 and 1588 show that American \\ drugs in Barcelona seem to have been \\ concentrated in the shop that belonged to Jeroni \\ Cercós (1558), who possessed canafistula and \\ carana. Nevertheless, the presence of American \\ drugs in the city and its environs is proved by the \\ tarifas of the Apothecaries Society (that is the \\ relations of substances in current use, whose
}


in the overland trade, inserted in the 1589 Venetian edition of Monardes' Dell' historia dei simplici an advertisement for the products of American materia medica that he had in his apothecary's shop-museum at the Campana de Oro. ${ }^{119}$ The fact that some pharmacists had semi-monopolies is shown by evidence that a Sevillian apothecary, Juan de Pineda, supplied, in 1551, American drugs to apothecaries from other towns, for example, sarsaparilla to Pedro de Aguilar, an apothecary from Lucena (Cordoba). ${ }^{120}$

Historians have argued that part of the evidence that the discovery of new medicinal plants had little impact on actual practice lies in the fact that the pharmacies were slow to stock them. ${ }^{121}$ I suggest that the absence of American drugs from Spanish and even Sevillian pharmacies must not be taken as an argument for stating categorically that American drugs did not influence medical practice. The amount imported and the existing evidence do not give much credibility to either of the previous hypotheses. This led me to consider the possibility that the new drugs were distributed outside the environment of the learned élite, in "an underground way". Different kinds of accounts give us an idea of how this may have happened.

We know from the writings of the early chroniclers that the new drugs soon became widely known. The fact that Spanish drugs deteriorated on the long voyage out to America led the early settlers to use indigenous plants. Pedro Arias de Benavides, a surgeon who practised in America and wrote a book after his return, explained, "The simples were damaged by the long period of storage in Spain, followed by a long sea voyage and then the time it took for them to be sold to apothecaries in the Indies. The merchants would hold on to them until there was a demand, and then the shops too kept the simples a long time; inevitably they were ruined." 122 This was why he and many others (not necessarily medical practitioners) experimented with the new drugs that were to be found in the new territories. Thus Monardes, referring to balsam, said that the Spaniards used it to cure their injuries, having been told of its virtues by the Indians. ${ }^{123}$

Another aspect, not widely addressed until now, is the early use of American plants for self-medication as a way of avoiding "the ignorance and misunderstandings of medical men". ${ }^{124}$ Fernández de Oviedo stated that in America rich people often used to cure their employees themselves without the help of

prices were frequently up-dated). See Ramón Jordi, 'Un estudio comparativo de medicamentos. Periodo 1364-1846', Circular Farmacéutica, 1992, 317: 13-56, p. 16. In the tarifa of 1585 are sarsaparilla, Mechoacan root and tacamahaca.

${ }^{119}$ See Pardo Tomás, op. cit., note 104 above, p. 78. The advertisement appeared on two unnumbered pages after fol. 347 .

${ }^{120}$ Fernández-Carrión, Valverde, op. cit., note 86 above, p. 30. This is the kind of information that can be found in archives that have not been systematically explored.

${ }^{121}$ Fernández-Carrión, Valverde, op. cit., note 86 above, p. 48, and Carlos Viesca Treviño,
'Nicolás Monardes y las plantas medicinales mexicanas', in P Aceves Pastrana, Farmacia, historia natural y química intercontinentales, Mexico, Universidad Autónoma Metropolitana, Unidad Xochimilco, 1995, pp. 35-43, on pp. 42-3.

${ }^{122}$ Quoted in José Luis Fresquet Febrer, La experiencia americana y la terapéutica en los "Secretos de Chirurgia" (1567) de Pedro Arias de Benavides, Universitat de Valencia, CSIC, 1993, pp. 94-5.

${ }^{123}$ Monardes, op. cit. , note 27 above, fol. 17v.

${ }^{124}$ Fernández de Oviedo, op. cit., note 16 above, vol. 1, p. 368 . 


\section{New World Materia Medica in Spanish Renaissance Medicine}

surgeons, ${ }^{125}$ who were regarded as practising learned medicine. It seems that, apart from the problems of availability of familiar European drugs, the Spanish physicians in America were distrusted, so self-experiments were made with new healing methods. Fernández de Oviedo's remark also implies that American drugs were used at home.

So it is clear that Spaniards in New Spain knew and used these drugs themselves. This makes very possible similar self-medication when they returned, and also the transfer of this new knowledge to others when they were back home. Fernández de Oviedo also referred to this self-experimentation as a way of assimilating knowledge. He mentions Juan de la Vega who experimented with purgative nuts in Spain in 1513, like many other people, without the supervision of a doctor, claiming that Spanish doctors did not know about the nuts or understand how to use them. De la Vega tested the drug on one of his nephews, who died as a consequence. Oviedo commented briefly, "From this he learnt". ${ }^{26}$

Another purgative was the fig tree of hell oil, which, according to Monardes, had been shown to have "greate vertues" and was used by many people in the Indies as well as in Spain and, similarly, he noted that tacamahaca had also been proved effective by experimentation. ${ }^{127}$

Information was spread by word of mouth, ${ }^{128}$ and by gifts and exchange. Writing about guaiacum, Monardes said that news of it was communicated by people who came from America to Seville. Afterwards it spread all over Spain, and later to the rest of the world. ${ }^{129}$ Fernández de Oviedo remarked that "Just as supplies were brought for His Majesty, so too they arrived for merchants and other individuals". ${ }^{130}$

Apart from the monopoly trade system, there is evidence of the existence of widespread private exchange between individuals from America to Spain although it is difficult to evaluate systematically. This private exchange may have been promoted because the trade in medicinal products was not seen as a way of making a big fortune by comparison with the trade in other products, such as sugar, for which there was more demand and profit. One documented example of a private exchange is Benavides' report that when he returned to Toro, his home town in Spain, he sent Bernardino del Castillo some presents because del Castillo had never asked for payment for plants of his own, including Mechoacan root, that he had given Benavides for medicinal use. ${ }^{131}$ Such exchanges may have well influenced a trade in cheaper drugs_-outside the merchants' control-between individuals from America and people in Spain. Travellers from America also often wanted to be healed with the products they had brought with them. ${ }^{132}$ Information in letters sent

\footnotetext{
${ }^{125}$ Ibid., vol. 1, p. 379.

${ }^{126}$ Ibid., vol. 1, p. 369.

${ }^{127}$ Monardes, op. cit., note 27 above, fol. $11 \mathrm{v}$.

${ }^{128}$ This aspect is pointed out by Carlos Viesca Treviño and Fernando Martínez Cortés, 'Plantas medicinales americanas. Su injerto en la medicina hipocrática', in Historia general de la medicina en Mexico. Vol. 2: Medicina novohispana, siglo XVI, ed. Alfredo López Austin and Carlos Viesca
}

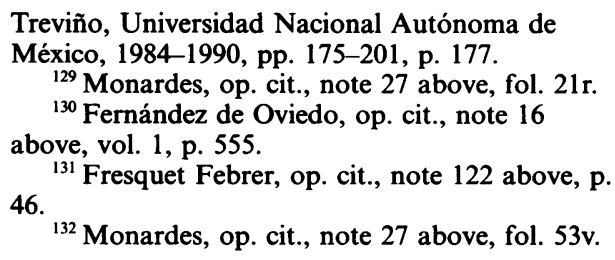




\section{Teresa Huguet-Termes}

from America to relatives in Spain confirms that this happened quite often, ${ }^{133}$ as well as pointing to another interesting fact: that women used American drugs in the home. As far as I know, the use of American drugs in private households has not yet been addressed.

Monardes mentions tacamahaca as being very popular for all kinds of pain, particularly among women, and refers to their curiosity in trying to mix it with other remedies such as amber or musk. ${ }^{134}$ Arias de Benavides, too, said that the women of Castille used this plant, and that it was imported by those who had travelled to the Indies. ${ }^{135}$ This seems to indicate that it was used by lay people and not just the medical profession.

García Ballester's studies of Morisco physicians also show that Morisco medical practitioners and their women knew about tacamahaca and used it. ${ }^{136}$ Since they belonged to a low, unpowerful and highly marginalized social group, this is another indication of the wide dispersal of drugs from the New World through all social levels. The Morisco practitioners based their therapy on two main vernacular books. One of them, already mentioned, was Fragoso's Discursos de las cosas aromaticas (1572), in which knowledge and uses of many American drugs were explained. The other was Laguna's edition of Dioscorides's Materia medica.

Another American drug which the poor used was balsam. It was very expensive at first, but Monardes stated that later, "After that they brought so muche and suche great quantity, that it is nowe of small valewe". This may have happened with some of the other expensive American drugs adopted as "unique" substitutes. The increased quantities imported and the fall of prices would have encouraged their use among the poorest social groupings, and this may have discouraged medical men from using them. Certainly, because balsam was very popular, Monardes wrote, "the use thereof is a common Medicine in all surgery of poore folkes: Seeyng that with one medicine all effectes is doen". ${ }^{137}$

But there is no reference to balsam in the case histories of Luis Mercado for the treatment of injuries and skin ailments, nor in the surgical treatises of Latinate surgeons, such as Juan Calvo (1536-99) and Fragoso, who were closer to the medical élite. Wealthy patients may have been reluctant to be treated with this popular and cheap remedy, and preferred, for instance, a ceite de Aparicio, a compound remedy made of ingredients found locally or imported from the East, much used for wound therapy. ${ }^{138}$ When Fragoso, in 1572, reported "the much higher quality of the aromatic plants of the Levant compared with those of our Indies", ${ }^{139}$ he bore witness to the still-important Levant trade and the possible

\footnotetext{
${ }^{133}$ Enrique Otte, 'Cartas privadas de Puebla del siglo XVI', Jahrbuch für Geschichte von Staat, Wirtschaft und Gesellschaft Lateinamerikas, 1966, 3: $10-87$, p. 22.

${ }^{134}$ Monardes, op. cit., note 27 above, fols. $7 v$ and $8 \mathrm{r}$.

${ }^{135}$ Fresquet Febrer, op. cit., note 122 above, p. 101.

${ }^{136}$ García Ballester, Los moriscos, op. cit., note 6 above, p. 155.
}

\footnotetext{
${ }^{137}$ Monardes, op. cit., note 27 above, fol. 19r; Frampton, op. cit., note 45 above, p. 25.

${ }^{138}$ José Luis Valverde, Pilar Arrébola, 'L'aide sanitaire apportée à la France par Philippe II', in XXVIII International Congress for the History of Medicine. Proceedings, Paris, Les Éditions de Médecine Pratique, 1983, p. 168.

${ }^{139}$ Fragoso, op. cit., note 49 above, fols. $4 r-5 v$.
} 


\section{New World Materia Medica in Spanish Renaissance Medicine}

existence of two parallel markets, the oriental one, most suitable for the therapy practised by learned physicians and directed at the rich, and the American one, much cheaper because of its being a "national" product. It seems that public health officers also were aware of the economic benefits of using certain American products. Towards the end of the century, ships of the navy were provided with canafistula, ${ }^{140}$ as was the apothecary of the Hospital de la Sta Creu of Barcelona in $1585 .{ }^{141}$ Although there existed an Indian species, the American species was much larger, and the cost-benefit relation seemed to be appreciated by public health officers.

On the other hand, the attitude of the royal court to the consumption of American drugs was important. During most of the second half of the sixteenth century the apothecaries who supplied the royal family and their servants did not depend directly upon the palace. The king used the services of wealthy apothecaries who supplied the court with the drugs prescribed by court physicians. During the second half of the sixteenth century, two groups of apothecaries held this position, the Arigon and Arenzano families, ${ }^{142}$ both of whom supplied the king with American drugs such as guaiacum and canafistula as early as 1545,1546 and $1547 .{ }^{143}$

\section{Conclusions}

My researches so far have produced more questions than answers, although I suggest that the use of American drugs in sixteenth-century Spain has been underestimated. The information contained in archives, especially the Archivo de Indias, has not been studied systematically regarding the subject of this paper. Other areas might produce interesting results. For instance, I have not been able to investigate in depth the use of these drugs by general surgeons and navy physicians, and in hospitals. Much more work needs to be done on the trade in drugs between Spain and other countries, and on the whole question of the impact of American drugs on European medicine at all social levels, but particularly at a practical level among low social groupings. Another interesting aspect I have not been able to go into is the cultivation of American drugs in Spain and elsewhere. Nevertheless, I think I have demonstrated that the practical impact of American products was a fact and that the medical establishment did not react against them as has been

\footnotetext{
${ }^{140}$ Pilar Arrébola, José Luis Valverde, 'Aprovisionamiento de medicamentos a galeones de la Armada en Lisboa (1591)', Boletín de la Sociedad Española de Historia de la Farmacia, 1985, 36 (141-142): 84.

${ }^{141}$ Ramón Jordi, 'Inventario incompleto perteneciente a la botica del Hospital de la Sta. Cruz de Barcelona (21-5-1585)', Circular Farmacéutica, 1982, 40: 272, 211 and 221.

${ }^{142}$ José Luis Valverde, Félix Sánchez López de Vinuesa, 'Las cuentas de la Real Botica
}

(1579-1616)', Actes XXVIIIth International Congress for the History of Medicine, Paris, Les Éditions de Médecine Pratique, 1983, pp. 291-6, p. 292.

${ }^{143}$ José Luis Valverde, Carmen Sánchez Téllez, 'Juan, José y Rafael de Arigón, boticarios reales (1544-47)', Ars Pharmaceutica, 1977, 18 (2): 217-58, pp. 223, 225. 
believed. ${ }^{144}$ Some drugs did enter Spain in large quantities and medical writers did make an effort to include some within the traditional Galenic medical schema of interpretation. But the big question still remains. Where did all the drugs imported into Spain then go?

${ }^{144}$ Although focusing on a period about a hundred years later, the model of assimilation and dispersal that Saul Jarcho proposes for quina seems to have some parallels with the model I have drawn, especially for the "new drugs". It would be interesting to do further comparative work. Saul Jarcho, Quinine's predecessor:

Francesco Torti and the early history of chinchona, Baltimore and London, Johns Hopkins University Press, 1993. 